\title{
Outras topografias da memória
}

\author{
Fernando Seliprandy
}

VIOLI, P.

Paesaggi della memoria:

il trauma, lo spazio, la storia.

Milão: Bompiani, 358 p., 2014.

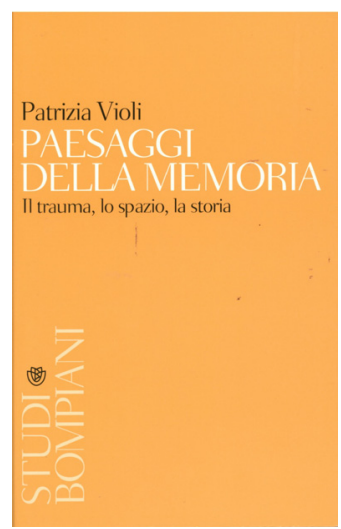

Resumo: O livro de Patrizia Violi trata de espaços ligados a memórias traumáticas. A abordagem se dá tanto em termos teóricos como pelo estudo de casos específicos no Camboja, na China, no Chile, na Argentina e na Itália. Museus, parques, centros culturais ou instalações artísticas são encarados como objetos carregados de sentidos que vão muito além do vínculo indicial entre lugar traumático e memória.

Palavras-chave: lugares; museu; memória; trauma; semiótica.

Abstract: Other topographies of memory - Patrizia Violi's book discusses the reinterpretation of spaces connected to traumatic memories. The approach is both theoretical and analytical of specific cases in Cambodia, China, Chile, Argentina, and Italy. Museums, parks, cultural complexes or art installations are regarded as objects bearing meanings far beyond the indexical link that exists between the traumatic site and the memory.

Keywords: sites; museum; memory; trauma; semiotics.

Espaços de memória, sejam museus, parques, centros culturais ou instalações artísticas, no Camboja, na China, no Chile, na Argentina e na Itália: o livro de Patrizia Violi, 
Paesaggi della memoria: il trauma, lo spazio, la storia, traz um olhar multifacetado para os lugares traumáticos. Com uma abordagem semiótica, a obra joga luz sobre processos variados, em termos geográficos, históricos e simbólicos, de transformação de locais onde foram perpetrados os maiores horrores em espaços de rememoração. Prisões, palcos de massacres, centros de tortura, destroços, enfim, epicentros de graves violações que, no desenrolar da história, tiveram sua macabra função original revertida nos termos da homenagem às vítimas e do alerta à sociedade.

Alguns desses traumas nos são próximos a nós brasileiros, não só pela vizinhança com Chile e Argentina, mas principalmente por nossa história compartilhada de ditaduras no passado recente. Outros traumas, contudo, nos soam mais distantes: os crimes do regime do Khmer Vermelho (1975-1979) no Camboja; as violações cometidas pelas tropas japonesas em Nanquim, em 1937; a trama internacional que encobre a "queda" do avião em Ustica, na Itália, em 1980. Traumas sobre os quais nós, no Brasil, sabemos muito ou quase nada. Em todos os casos, porém, são traumas "periféricos".

Mas "periféricos" em relação a qual centro? Patrizia Violi não se esquiva de nomeá-lo ao defender "a necessidade de colocar em discussão uma visão do trauma ainda excessivamente eurocêntrica e baseada exclusivamente sobre aquele que aos nossos olhos se apresenta como o trauma por excelência: o Holocausto." (2014, p. 12, grifo da autora, tradução nossa). Desde a Europa, Violi professa a descentralização do olhar para os traumas. Curioso é que aqui, no Cone Sul, os estudos sobre a memória das ditaduras muitas vezes insistem em transpor, sem maiores reflexões, a matriz teórica do Holocausto para as experiências locais.

Ora, não se trata de uma questão "geopolítica". O problema é de ordem teórica. Afinal, segundo Violi, é preciso "superar toda formulação universalizante e ontológica da noção de trauma para pensá-lo, antes, como uma categoria a ser declinada sempre no plural, indagando as modalidades diversas que assume de tempos em tempos" (2014, p. 13, tradução nossa). O que está em jogo, enfim, é a perda da especificidade histórica resultante de uma visão absolutizante do trauma, da transformação do Holocausto em paradigma universal. Esse deslocamento do olhar em nome da historicidade dos traumas já faz do livro de Patrizia Violi obra fundamental. Mas esse é apenas o ponto de partida.

Em seus sete capítulos, o livro atravessa temas centrais dos estudos da memória. Nos primeiros dois isso se dá em termos propriamente teóricos. Neles a autora percorre as principais discussões acerca da memória do trauma e sua dimensão espacial, tensionando certos tópicos recorrentes nesse campo do pensamento. As reflexões miram sempre a desnaturalização dos nexos indiciais entre os espaços de memória e os eventos passados, a autora, lembrando que, nada, nem a marca do trauma mais terrível pode ser tomada como um dado imediato, que tudo passa pela mediação semiótica. Violi, contudo, não ignora a potência do traço indicial, os efeitos empáticos e de autenticidade derivados do fato de o lugar de rememoração ser exatamente o mesmo onde se perpetraram 
os horrores rememorados. Cumpre à análise não sucumbir a essa força indicial, levando em conta tudo aquilo que cabe no espaço que separa o evento de seus sentidos.

Vale dizer que tal espaço não é um abismo intransponível entre o passado e sua representação. A proposta de Violi afasta-se de qualquer ideia de irrepresentável: "na nossa perspectiva, não se tratará tanto de se interrogar se o trauma é ou não representável, mas como se escolhe mostrá-lo, contá-lo, elaborá-lo, por meio de quais rastros, segundo quais mediações, com quais vozes e quais olhares." (2014, p. 51, grifo da autora, tradução nossa). É esse "como" que se multiplica no espaço entre fato e sentidos, delineando as possíveis releituras dos lugares traumáticos, em uma gama cujos extremos seriam a conservação obsessiva e a espetacularização do horror.

Os cinco capítulos subsequentes estão dedicados às análises dos estudos de caso, mobilizando o arcabouço teórico construído nos dois capítulos acima citados. Primeiro, o evento cambojano, o Museu do Genocídio Tuol Sleng e sua preservação do lugar do horror "tal qual era", apelando aos sentidos muito mais do que ao conhecimento de razões e responsabilidades. Em seguida, o caso chinês, o Memorial Hall de Nanquim, espécie de parque temático faraônico dedicado à exaltação de uma nação e de um povo. Depois, o chileno, com destaque para o parque deVilla Grimaldi e seus espaços e sentidos abertos. Ainda, o argentino, com a ex-Esma abrigando as mais divergentes visões sobre como se deve lidar com o passado traumático. Por fim, o caso italiano, a instalação artística alusiva ao desastre de Ustica, na qual destroços e imaginação se integram em prol da memória das vítimas.

Alguns leitores podem questionar a opção por separar as considerações teóricas e as análises dos casos. Mas a verdade é que, embora apresentadas separadamente, as partes não são estanques, teoria e análise iluminam-se reciprocamente. Além disso, os capítulos teóricos trazem um aporte de fôlego não só para os estudos de caso abordados no livro. Muitos outros exemplos de lugares de memória, em inúmeros países, podem ser pensados a partir do livro de Patrizia Violi.

É, nomeadamente, o nosso caso, o caso brasileiro. Afinal, os espaços de memória dedicados às violações da ditadura deveriam estar hoje, mais do que nunca, na ordem do dia. Pois é urgente rememorar esse passado, sobretudo na conjuntura presente, quando setores da sociedade, cada vez com mais estridência, não se acanham em minimizar os traumas ainda vigentes do autoritarismo.

Fernando Seliprandy é doutorando em História Social na FFLCH/USP. É autor de A luta armada no cinema: ficção, documentário, memória (São Paulo: Intermeios, 2015). Integra o grupo de pesquisa CNPq "História e audiovisual: circularidades e formas de comunicação".

seliprandy@usp.br 